\title{
Evaluation of Candida albicans formation on feldspathic porcelain subjected to four surface treatment methods
}

\author{
Banu KARAYAZGAN ${ }^{1}$, Arzu ATAY², Mehmet Ali SARACLI ${ }^{3}$ and Yumushan GUNAY² \\ ${ }^{1}$ Department of Prosthodontics, Faculty of Dentistry, Baskent University,Mahir Iz Cad No:43 34662, Altunizade, Istanbul, Turkey \\ ${ }^{2}$ Department of Prosthodontics, Dental Clinic, GATA HaydarpasaTraining Hospital, Tibbiye Cad, 81327,Haydarpasa, Istanbul, Turkey \\ ${ }^{3}$ Department of Clinical Microbiology, Gulhane Military Medical Academy, 06018, Etlik, Ankara, Turkey \\ Corresponding author, Yumushan GUNAY; E-mail: yumushangunay@gmail.com
}

\begin{abstract}
Candida albicans, known for its adhesion on prosthetic materials and oral tissues, is the most frequently encountered fungal infection in dentistry. The aim of this study was to evaluate the effects of four different surface treatment methods and immersion in artificial saliva on the surface roughness of and candida adhesion on dental porcelains. The four surface treatment methods were namely: natural glaze, overglaze, dual ion exchange, and polishing. Surface roughness of porcelain was evaluated using a surface profilometer and by SEM. Candida adhesion was examined by culturing two Candida strains on porcelain specimens followed by a colorimetric method using XTT/Coenzyme Q0. It became evident that Candida adhesion was found more in the specimens treated with natural glaze and polishing. Further, by the visual inspection of SEM images and comparison of surface roughness, polished and naturalglazed specimens showed rougher surface characteristics than overglazed and dual-ion-exchanged specimens.
\end{abstract}

Keywords: Candida albicans, Feldspathic porcelain, Surface treatment

Received Feb 23, 2009: Accepted Nov 9, 2009

\section{INTRODUCTION}

Feldspathic porcelain has been frequently used in fixed dental restorations because of its outstanding esthetic and biocompatible features ${ }^{11}$. However, due to its brittle nature after firing, various surface treatment procedures need to be applied on the porcelain surface in order to strengthen the material and inhibit fractures, thereby increasing its long-term use. To date, several methods for surface treatment prior to final cementation have been introduced ${ }^{2,3}$, and they are namely: natural glaze, overglaze, dual ion exchange, and polishing.

Autogenous or natural glaze results from vitrification of the surface when it is heated up to a glazing temperature. Low-fusing glaze powder is applied evenly on the veneer and fired up to its maturation temperature ${ }^{4 \cdot 6)}$. In overglaze procedure, overglaze powder is applied on the porcelain surface and heated up to a temperature close to the firing temperature $\mathrm{e}^{6,7)}$. In dual ion exchange method, sodium ions are replaced by larger potassium ions on the porcelain surface. During the initial phase of this method, sodium and potassium ions are exchanged for smaller lithium ions at a temperature above the melting point of the ceramic, and then the smaller lithium ions are exchanged for sodium ions at a temperature below the melting point of the ceramic. The main advantage of this technique is the development of an ion-exchanged layer with greater strength $^{1,6,8)}$. As for polishing, which is another alternative for the finishing procedure, it differs from the dual ion exchange method in that it does not affect the chemical structure of porcelain. This method reduces surface roughness by employing various finishing burs with different grit sizes.
Candida albicans (C. albicans), the most frequently encountered intraoral commensal is an opportunistic and toxic pathogen ${ }^{9}$. It accounts for $25 \%$ of the intraoral microorganisms in healthy individuals and $50-90 \%$ in individuals with immunosuppressive or various health problems ${ }^{10)}$. On the adhesion mechanism of this microorganism on intraoral prosthetic materials, numerous research studies have been conducted to examine this concern and gain more insight ${ }^{11-18)}$. Paling in comparison, on the other hand, are the investigative efforts on the effects arising from the surface variations of porcelain materials, and the related long-term alterations, on Candida adhesion.

To quantitatively measure C. albicans adhesion, various methods have been proposed - such as colony counting, radiolabeling, and antibody assays. These procedures, however, are tedious, expensive, and timeconsuming. With regard to assaying the adhesion of $C$. albicans on non-biological materials, the quantitative colorimetric method has emerged as one of the most efficient and cost-effective methods. In particular, XTT assay employs the oxidation of 2,3-bis(2-methoxy-4nitro-5-sulfophenyl)-5-[(phenyl-a mino)carbonyl]-2Htetrazolium hydroxide, which is a tetrazolium salt, to 3-(4,5-dimethylthiazole-2-yl)-2,5-diphenyltetrazolium bromide. The XTT assay monitors and measures the metabolic activity, and it has been proved to be a simple, rapid, and reliable colorimetric method for quantitative determination of $C$. albicans adhesion on the surfaces of diverse materials ${ }^{12,19-23)}$.

Based on published literature, the porcelain surface presents the least potential for the adhesion and biofilm formation of C. albicans ${ }^{2,6,16,17)}$. However, to the best of the authors' knowledge, no research has been conducted to endorse the preferred choice of surface treatment vis-à-vis Candida adhesion and 
formation. Therefore, the aim of this study was to develop an in vitro model to quantitatively determine the adhesion of two strains of $C$. albicans on feldspathic porcelain subjected to four different surface treatment methods. After aging was performed in artificial saliva, quantitative measurement was carried out using XTT assay. For better insight into surface characterization in the long term, surface roughness was also measured and the values compared with the SEM images.

\section{MATERIALS AND METHODS}

\section{Specimen preparation}

A total of 88 feldspathic porcelain disks (VMK 95, shade A2, Vita Zahnfabrik, Bad Sackingen, Germany), of $5 \mathrm{~mm}$ diameter and $2 \mathrm{~mm}$ thickness, were prepared for this study. The test disks were fabricated according to the manufacturer's recommendations by mixing porcelain powder $(1.3 \mathrm{~g})$ with a modeling fluid $(0.3 \mathrm{cc})$. The slurry was vibrated and condensed into a resin mold, and excess fluid was absorbed using a paper tissue.

The specimens were vacuum-fired in a porcelain furnace (Vacumat 200, Vita Zahnfabrik, Bad Sackingen, Germany) at an initial temperature of $600^{\circ} \mathrm{C}$ for 5 minutes. The temperature was gradually increased at a rate of $100{ }^{\circ} \mathrm{C} /$ minute until it reached $940^{\circ} \mathrm{C}$, then rapid air cooling was applied.

One side of each disk was ground with a $70-\mu \mathrm{m}$ diamond abrasive wheel using a 300-rpm grinding machine. After polishing, the disks were cleaned with distilled water in an ultrasonic cleaner for 10 minutes. A single investigator was assigned to prepare the specimens in the same manner to ensure standardization.

The prepared specimens were assigned into four experimental groups according to their surface treatment methods - namely, natural glaze, overglaze, dual ion exchange, and polishing.

1. Natural glaze method

Natural glaze (Vita Zahnfabrik, Bad Sackingen, Germany) was performed in a porcelain furnace (Vakumat 200, Vita Zahnfabrik, Bad Sackingen, Germany) according to the manufacturer's recommendations at an initial temperature of $600^{\circ} \mathrm{C}$ for 5 minutes. The temperature was gradually increased at a rate of $100{ }^{\circ} \mathrm{C} /$ minute until it reached $940^{\circ} \mathrm{C}$, then rapid air cooling was applied.

\section{Overglaze method}

Overglaze powder (Vita Zahnfabrik, Bad Sackingen, Germany) was mixed with deionized water and applied on the surfaces of the porcelain disks to create a layer of approximately $0.3 \mathrm{~mm}$ thickness. Glaze sintering was performed in a porcelain furnace (Vakumat 200, Vita Zahnfabrik, Bad Sackingen, Germany) at $600^{\circ} \mathrm{C}$ with a dwell time of 3 minutes. The temperature was then increased at a rate of $100{ }^{\circ} \mathrm{C} /$ minute until it reached $920^{\circ} \mathrm{C}$. Dwell time for the latter sintering temperature was 1 minute, and then rapid air cooling was applied.

\section{Dual ion exchange method}

Disk specimens were coated with slurries ranging from $10 \mathrm{~mol} \%$ lithium chloride ( $\mathrm{LiCl}$ ) to $90 \mathrm{~mol} \%$ sodium chloride $(\mathrm{NaCl})$ in distilled water. The coated disks were heat-treated at $750^{\circ} \mathrm{C}$ for 30 minutes and then at $450^{\circ} \mathrm{C}$ for 30 minutes.

4. Polishing method

For the initial polishing of the porcelain disks, it was performed using a 50- $\mu \mathrm{m}$ diamond wheel (ECOMET III, Buehler Ltd., Lake Bluff, IL, USA). This was followed by a $35-\mu \mathrm{m}$ diamond wheel, and then $15-\mu \mathrm{m}$ diamond paste (Cosmedent Inc., Chicago, IL, USA) on a cloth wheel (ECOMET III, Buehler Ltd., Lake Bluff, IL, USA). A polisher (ECOMET, Buehler Ltd., Lake Bluff, IL, USA) was used to ensure the reproducibility of the polishing procedure. A pressure of $66.72 \mathrm{~N}$ for 15 seconds at a speed of $350 \mathrm{rpm}$ was applied to the porcelain surfaces for each of the two diamond grit sizes. The disks were cleaned in a soap solution (Evyap Tic AS., Levent, Istanbul, Turkey) in an ultrasonic device, and then finally in deionized water.

\section{Artificial saliva immersion}

All specimens were rinsed twice with sterile water, then placed in an artificial saliva solution $(1.0 \mathrm{~mL} / \mathrm{well}$; $4.1 \mathrm{mM} \mathrm{KH} \mathrm{PO}_{4}, 4.0 \mathrm{mM} \mathrm{Na}_{2} \mathrm{HPO}_{4}, 24.8 \mathrm{mM} \mathrm{KHCO}$, $16.5 \mathrm{mM} \mathrm{NaCl}, 0.25 \mathrm{mM} \mathrm{MgCl}, 4.1 \mathrm{mM}$ citric acid, and $\left.2.5 \mathrm{mM} \mathrm{CaCl}_{2} ; \mathrm{pH} 6,7\right)$ at $37^{\circ} \mathrm{C}$. The specimens were disinfected and cleaned as previously described, then tested for adhesion after 2 weeks of immersion in artificial saliva.

One specimen from each experimental group was used for SEM analysis and surface roughness evaluation. The remaining specimens of each experimental group were used for C. albicans adhesion investigation.

\section{Surface topography}

After immersion in saliva, the effects of four surface treatment methods were evaluated using a scanning electron microscope (SEM) (JSM 6400, JEOL Ltd., Tokyo, Japan). The disks were sputter-coated with 25 $\mathrm{nm}$ gold, and surface images of $\times 500$ magnification were used for topographical evaluation and comparison.

Surface roughness (Ra) was measured using a profilometer (Mitutoyo Surftest 402 Analyzer, Mitutoyo Corp., Kawasaki, Japan). The profilometer was calibrated with a standard reference specimen, and then set to travel at a speed of $0.100 \mathrm{~mm} / \mathrm{s}$ with a range of $600 \mu \mathrm{m}$ during testing. To measure the $R \mathrm{a}$ value, the diamond stylus (5- $\mu \mathrm{m}$ tip radius) was moved across the surface under a constant load of $3.9 \mathrm{mN}$. The surface analyzer was used to determine the roughness profile of each specimen. This procedure was repeated three times at different locations to obtain the general characteristic of the surface.

Quantitative measurement of Candida adhesion

Quantitative measurements were made using ELISA readings (EL800, Bio-Tek Instruments, ABD) before 
and after immersion in artificial saliva. Adhesion measurement was performed using a modified technique as introduced by Sen et $a l .{ }^{20)}$ and Ramage et $a l .^{24)}$.

Two Candida strains were used in this study: GDH 2346 and a clinical strain known for its adhesion to YPD medium ( $1 \%$ yeast extract, $2 \%$ peptone, $2 \%$ dextrose). Five identical colonies of each strain were inoculated in YPD liquid medium and grown overnight at $37^{\circ} \mathrm{C}$ in a shaking incubator (100 rpm). Pellets which were obtained after 10-minute centrifugation at $5,000 \mathrm{rpm}$ were washed twice with PBS $(8.0 \mathrm{~g} \mathrm{NaCl}$, $0.2 \mathrm{~g} \mathrm{KCl}, 1.15 \mathrm{~g} \mathrm{Na}_{2} \mathrm{HPO}_{4}, 0.2 \mathrm{~g} \mathrm{KH} \mathrm{KO}_{4}, 1000 \mathrm{ml}$ $\mathrm{dH}_{2} \mathrm{O}$ ) adjusted to $\mathrm{pH}$ 7.2. Cell concentration was standardized to $1.0 \times 10^{6}$ cells $/ \mathrm{ml}$. These cells were suspended in RPMI 1640 medium (ICN-Flow, Aurora, $\mathrm{OH}$, USA) and buffered with 3-(N-morpholino) propanesulphonic acid (MOPS; ICN-Flow, Aurora, OH, USA). Standard yeast cell suspensions of $4 \mathrm{ml}$ were added into six cell culture vials containing sterile porcelain disks and incubated at $37^{\circ} \mathrm{C}$ in a shaking incubator $(60 \mathrm{rpm})$ for 2 weeks.

After incubation, the porcelain disks were removed and washed twice with sterile PBS solution. The disks were then placed in 24 sterile cell culture vials, to which were added a mixture of $1 \mathrm{ml}$ of sterile PBS and $500 \mu \mathrm{l}$ of XTT/Coenzyme $Q_{0}(0.5 \mathrm{mg} / \mathrm{ml}$ XTT in $40 \mu \mathrm{g} / \mathrm{ml}$ $\left.\mathrm{CoQ}_{0} / \mathrm{PBS}\right)$. After incubation at $37^{\circ} \mathrm{C}$ for 2 hours, the liquid part was transferred into microcentrifuge tubes and centrifuged at 10,000 rpm for 2 minutes. Liquid specimens of $100 \mathrm{ml}$ each were collected and transferred into microplates, and then their optical densities (OD) measured at $490 \mathrm{~nm}$ with an ELISA reader. The $\mathrm{OD}$ value of XTT/Coenzyme $\mathrm{Q}_{0}$ mixture was excluded from all the ELISA readings. Each quantitative measurement was done three times.

\section{Statistical analysis}

Results obtained in this study were statistically analyzed using SPSS (Statistical Package for Social Sciences SPSS, Chicago, IL, USA) for Windows 13.0. Definitive statistical methods (mean, standard deviation, median) were employed in the determination of the results. Mann-Whitney $U$ tests were used to compare the differences within groups and between groups before and after immersion in artificial saliva. The relation of XTT/CoQ0 variable with the other variants was investigated using Pearson's correlation coefficient. For surface roughness, the mean $R$ a values were analyzed using one-way analysis of variance and Tukey's HSD test at 5\% significance level.

\section{RESULTS}

\section{Surface topography}

Surface roughness $(R \mathrm{a})$ measurements before and after immersion in artificial saliva were compared, and no statistically significant changes $(p>0.05)$ were observed for the overglazed and dual-ion-exchanged specimens. On the contrary, statistically significant differences $(p<0.05)$ were observed for the specimens treated with polishing and natural glaze (Table 1).

SEM analysis revealed that overglaze and dual ion exchange treatments rendered a smoother, slightly pitted surface than the specimens treated with natural glaze and polishing. For overglazed and dual-ionexchanged specimens (Figs. 2 and 3 respectively), their surface topographies became similar after immersion in artificial saliva. As for the natural-glazed and polished specimens (Figs. 1 and 4 respectively), their surfaces were observed to be slightly rougher after immersion, whereby the roughness of the polished surface seemed to be greater than that of the natural-glazed surface.

In summary, evidently rough surfaces were seen for natural-glazed and polished specimens through SEM observation with accompanying high $R$ a values. On the contrary, smoother surfaces were observed for overglazed and dual-ion-exchanged specimens with accompanying lower $R$ a values.

\section{Adhesion of the clinical strain of Candida}

For the clinical strain specimens (Table 2; Fig. 5), the natural glaze treatment resulted in significant differences $(p=0.04)$ before and after immersion in artificial saliva. Similarly, significant differences $(p=0.04)$ were observed for the polished specimens before and after immersion in saliva. In contrast, no statistically significant differences were observed for the overglazed specimens $(p=0.16)$ and dual-ionexchanged specimens $(p=0.39)$ before and after immersion.

Upon comparing among the four different surface treatment methods (Table 4), statistically significant differences were observed between the natural-glazed and dual-ion-exchanged specimens and between the natural-glazed and polished specimens before

Table 1 Surface roughness values $(\mu \mathrm{m})$ of the specimens before and after immersion in artificial saliva

\begin{tabular}{lccccc}
\hline & \multicolumn{2}{c}{ Before Immersion } & \multicolumn{2}{c}{ After Immersion } \\
\hline Surface Treatment & Mean & SD & Mean & SD & Sig. \\
\hline Natural glaze & 0.67 & 0.34 & 1.17 & 0.43 & $<0.05$ \\
Overglaze & 0.58 & 0.36 & 0.59 & 0.28 & $>0.05$ \\
Dual ion exchange & 0.61 & 0.24 & 0.67 & 0.23 & $>0.05$ \\
Polishing & 0.74 & 0.39 & 1.26 & 0.48 & $<0.05$ \\
\hline
\end{tabular}



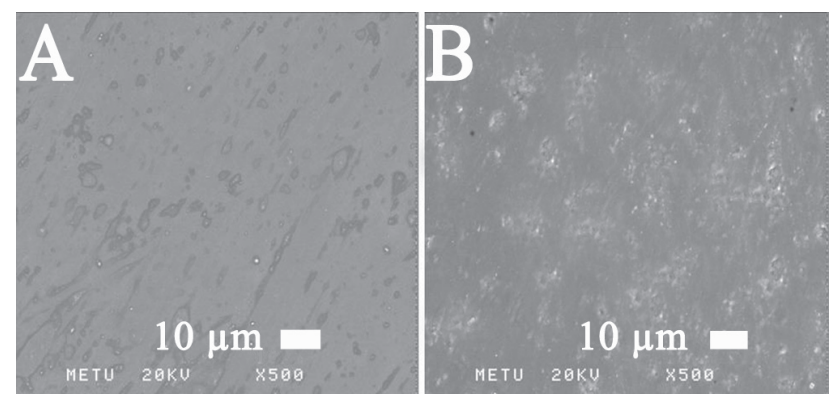

Fig. 1 Surface topography of natural-glazed specimens before (A) and after (B) immersion in saliva $(\times 500$ magnification).

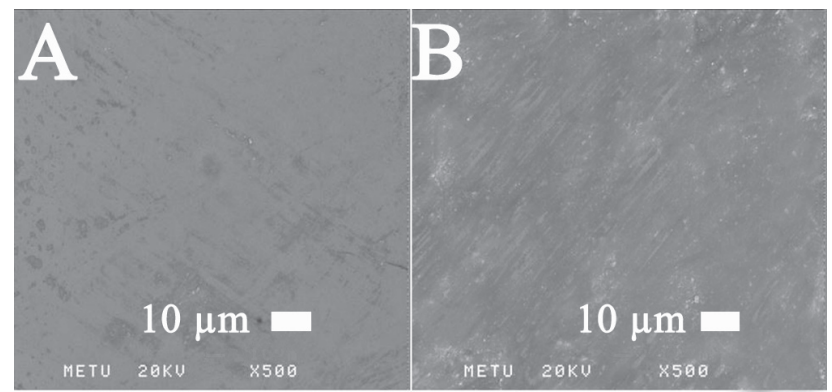

Fig. 2 Surface topography of overglazed specimens before (A) and after (B) immersion in saliva $(\times 500$ magnification).
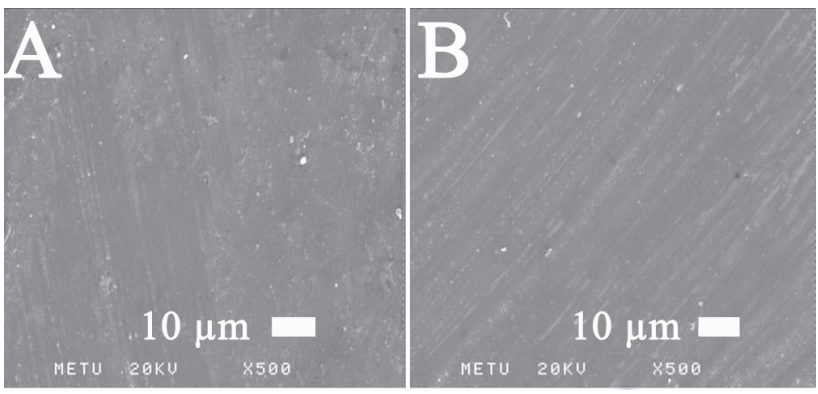

Fig. 3 Surface topography of dual-ion-exchanged specimens before (A) and after (B) immersion in saliva (×500 magnification)
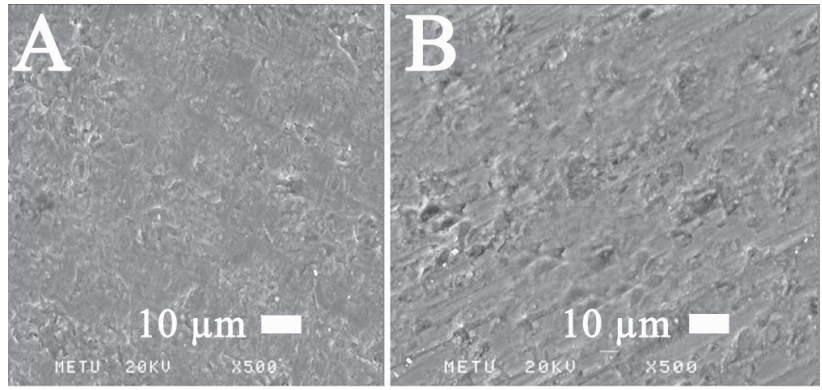

Fig. 4 Surface topography of polished specimens before (A) and after (B) immersion in saliva $(\times 500$ magnification).

Table 2 Mann-Whitney U test results for the clinical strain before and after immersion in artificial saliva

\begin{tabular}{|c|c|c|c|c|c|c|c|c|}
\hline \multicolumn{2}{|c|}{ Clinical strain } & Minimum & Maximum & Mean & $\mathrm{SD}$ & Median & $\mathrm{Z}$ & $p$-value \\
\hline \multirow{2}{*}{ Natural glaze } & Before immersion & 0.12 & 0.14 & 0.134 & 0.007 & 0.135 & \multirow{2}{*}{-2.02} & \multirow{2}{*}{0.04} \\
\hline & After immersion & 0.12 & 0.173 & 0.1493 & 0.019 & 0.155 & & \\
\hline \multirow{2}{*}{ Overglaze } & Before immersion & 0.12 & 0.15 & 0.135 & 0.010 & 0.14 & \multirow{2}{*}{-1.39} & \multirow{2}{*}{0.16} \\
\hline & After immersion & 0.12 & 0.16 & 0.14 & 0.013 & 0.14 & & \\
\hline \multirow{2}{*}{$\begin{array}{l}\text { Dual ion } \\
\text { exchange }\end{array}$} & Before immersion & 0.12 & 0.15 & 0.138 & 0.009 & 0.14 & \multirow{2}{*}{-0.85} & \multirow{2}{*}{0.39} \\
\hline & After immersion & 0.12 & 0.18 & 0.143 & 0.022 & 0.14 & & \\
\hline \multirow{2}{*}{ Polishing } & Before immersion & 0.13 & 0.15 & 0.141 & 0.006 & 0.14 & \multirow{2}{*}{-2.05} & \multirow{2}{*}{0.04} \\
\hline & After immersion & 0.13 & 0.18 & 0.153 & 0.016 & 0.15 & & \\
\hline
\end{tabular}

Table 3 Mann-Whitney U test results for the GDH 2346 strain before and after immersion in artificial saliva

\begin{tabular}{|c|c|c|c|c|c|c|c|c|}
\hline \multicolumn{2}{|c|}{ GDH 2346 strain } & \multirow{3}{*}{$\begin{array}{c}\text { Minimum } \\
0.12 \\
0.12\end{array}$} & \multirow{3}{*}{$\begin{array}{c}\text { Maximum } \\
0.14 \\
0.5\end{array}$} & \multirow{3}{*}{$\begin{array}{c}\text { Mean } \\
0.135 \\
0.184\end{array}$} & \multirow{3}{*}{$\begin{array}{c}\text { SD } \\
0.007 \\
0.112\end{array}$} & \multirow{3}{*}{$\begin{array}{c}\text { Median } \\
0.14 \\
0.15\end{array}$} & \multirow{3}{*}{$\begin{array}{c}\mathrm{Z} \\
-1.97\end{array}$} & \multirow{3}{*}{$\begin{array}{c}p \text {-value } \\
0.04\end{array}$} \\
\hline \multirow{2}{*}{ Natural glaze } & Before immersion & & & & & & & \\
\hline & After immersion & & & & & & & \\
\hline \multirow{2}{*}{ Overglaze } & Before immersion & 0.12 & 0.15 & 0.136 & 0.010 & 0.135 & \multirow{2}{*}{-0.45} & \multirow{2}{*}{0.65} \\
\hline & After immersion & 0.13 & 0.16 & 0.137 & 0.009 & 0.135 & & \\
\hline \multirow{2}{*}{$\begin{array}{l}\text { Dual ion } \\
\text { exchange }\end{array}$} & Before immersion & 0.12 & 0.15 & 0.137 & 0.008 & 0.14 & \multirow{2}{*}{-0.43} & \multirow{2}{*}{0.67} \\
\hline & After immersion & 0.12 & 0.16 & 0.139 & 0.012 & 0.14 & & \\
\hline \multirow{2}{*}{ Polishing } & Before immersion & 0.14 & 0.15 & 0.141 & 0.003 & 0.14 & \multirow{2}{*}{-1.99} & \multirow{2}{*}{0.04} \\
\hline & After immersion & 0.13 & 0.18 & 0.155 & 0.019 & 0.15 & & \\
\hline
\end{tabular}


Table 4 Mann-Whitney U test results for the binary comparison of the different surface treatment methods

\begin{tabular}{lcccc}
\hline & \multicolumn{2}{c}{ Clinical strain } & \multicolumn{2}{c}{ GDH 2346 } \\
\cline { 2 - 5 } & $\begin{array}{c}\text { Before Immersion } \\
(\mathrm{Z} ; p \text {-value })\end{array}$ & $\begin{array}{c}\text { After Immersion } \\
(\mathrm{Z} ; p \text {-value })\end{array}$ & $\begin{array}{c}\text { Before Immersion } \\
(\mathrm{Z} ; p \text {-value })\end{array}$ & $\begin{array}{c}\text { After Immersion } \\
\text { (Z; } p \text {-value) }\end{array}$ \\
\hline Natural glaze - Overglaze & $-0.37 ; 0.71$ & $-1.27 ; 0.2$ & $-0.12 ; 0.9$ & $-2.18 ; 0.03$ \\
Natural glaze -Dual ion exchange & $-2.2 ; 0.03$ & $-0.35 ; 0.73$ & $-0.65 ; 0.52$ & $-1.7 ; 0.09$ \\
Natural glaze - Polishing & $-2.2 ; 0.03$ & $-0.35 ; 0.73$ & $-2.29 ; 0.02$ & $-0.08 ; 0.94$ \\
Overglaze - Dual ion exchange & $-0.69 ; 0.49$ & $0 ; 0.99$ & $-0.36 ; 0.72$ & $-0.48 ; 0.63$ \\
Overglaze - Polishing & $-1.5 ; 0.13$ & $-1.78 ; 0.08$ & $-1.5 ; 0.13$ & $-2.43 ; 0.01$ \\
Dual ion exchange - Polishing & $-0.73 ; 0.47$ & $-1.35 ; 0.18$ & $-0.36 ; 0.72$ & $-0.48 ; 0.63$ \\
\hline
\end{tabular}

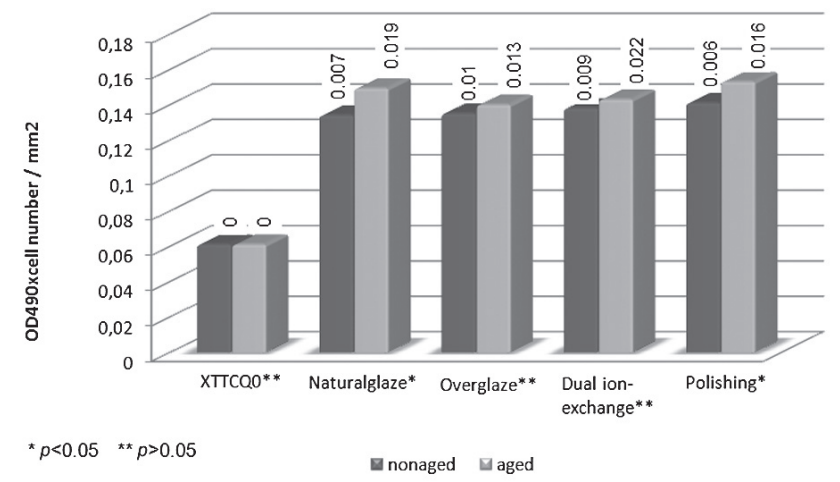

Fig. 5 Adhesion of the clinical strain on porcelain disks subjected to four surface treatments with and without aging in artificial saliva.

immersion in saliva $(p<0.05)$. After immersion, there were no statistically significant differences among the four surface treatment methods.

\section{Adhesion of GDH 2346 strain}

For the GDH 2346 strain (Table 3; Fig. 6), statistically significant differences were likewise observed for the natural-glazed and polished specimens before and after immersion in artificial saliva $(p=0.04)$. However, no statistically significant differences were observed for the overglazed $(p=0.65)$ and dual-ion-exchanged $(p=0.67)$ specimens before and after immersion.

Upon comparing among the four different surface treatment methods (Table 4), a significant difference $(p<0.05)$ was observed between the natural-glazed and polished specimens before immersion. After immersion, significant differences $(p<0.05)$ were observed between the natural-glazed and overglazed specimens and between the overglazed and polished specimens.

\section{DISCUSSION}

The effects of different surface treatments - namely, natural glaze, overglaze, ion exchange, and polishing - on strength have been widely mentioned in published literature ${ }^{1-4,6-8,23,25)}$, but not so with their

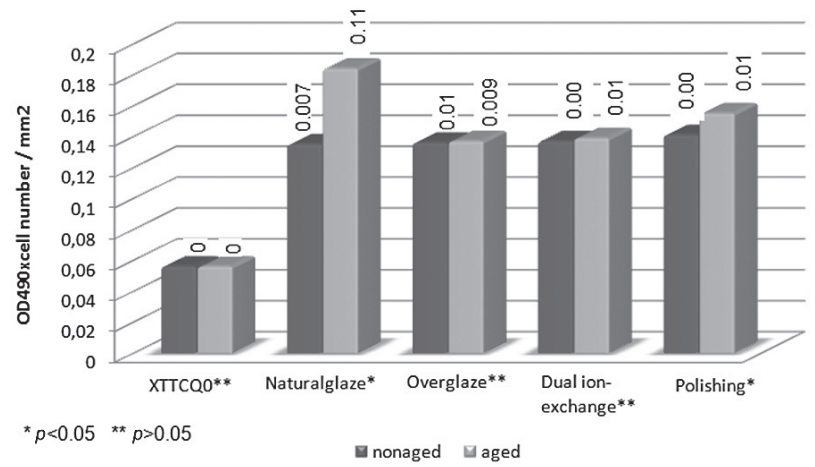

Fig. 6 Adhesion of GDH 2346 on porcelain disks subjected to four surface treatments with and without aging in artificial saliva.

effects on Candida adhesion on porcelain surfaces ${ }^{16,17)}$. Against this backdrop of information scarcity, this study was undertaken to investigate the effects of different surface treatments on the adhesion and formation of $C$. albicans.

In the evaluation of Candida formation on several non-porcelain dental materials, surface roughness and aging in saliva were considered to be pivotal factors to the long-term success of these dental materials ${ }^{14,16,17,25)}$. However, similar research efforts pale in comparison for the porcelain surface ${ }^{13,15-17,22,23)}$. Therefore, in this study, both surface roughness and aging in saliva were included as primary determinants in the evaluation of C. albicans adhesion on the porcelain material.

For the quantitative measurement of Candida adhesion, XTT assay has been shown by Sen et $a l .^{20)}$ and Ramage et $a ._{.}{ }^{24)}$ to be a more advantageous microbiologic tool. Therefore, the XTT method was used in this study to assess Candida adhesion on porcelain surfaces with different surface characteristics.

On the preferred surface treatment for dental porcelains, discrepant conclusions abound in the published literature. In studies that have compared polishing and glazing, differing results were obtained ${ }^{1,3,5-8)}$. Nonetheless, since glazed porcelain 
provides a dense and smoother surface, some studies supported that polishing can serve as an alternative to glazing ${ }^{1,3)}$.

On Candida adhesion, Radford et $a .^{15}{ }^{15}$ demonstrated that there was no direct relationship between surface roughness and adhesion, irrespective of the material. On the other hand, Wang et al. ${ }^{16)}$ demonstrated that more bacteria adhered on a rougher porcelain surface. In the present study, higher surface roughness $(R a)$ values were obtained for natural-glazed and polished specimens after immersion. In parallel with these results, a higher level of Candida adhesion was observed for natural-glazed and polished specimens. Based on these results, it could be said that as the surface became rougher, a higher level of $C$. adhesion was observed. Therefore, to eliminate Candida formation, the porcelain surface should not be subjected to polishing or natural glaze treatment.

In a study by Fuzzi et $a l^{3)}$, SEM images of porcelain specimens revealed considerable changes to the surface characteristics. It was also found that overglazing produced a better surface than the polishing methods ${ }^{3}$. In the present study, SEM observation likewise showed that polished and naturalglazed specimens presented rougher surfaces when compared with overglazed and dual-ion-exchanged specimens.

At this juncture, it must be pointed out that the dual ion exchange technique used in this study is an in vitro method rather than a routine laboratory procedure. Although this technique seemed to provide a smoother surface for preventing Candida adhesion, it did not carry a strong significance as it is not used in clinical practice. For the other three surface treatment methods investigated in this study, results showed that both polishing and natural glaze resulted in higher Candida formation. Therefore, overglaze should be the preferred method in preventing C. albicans adhesion. Moreover, both the $R$ a values and SEM images obtained supported the result obtained with the XTT test.

\section{CONCLUSIONS}

Within the limitation of this study, the following conclusions were drawn:

1. Surface treatment had an effect on C. albicans formation. In particular, a higher level of Candida adhesion was observed on naturalglazed and polished surfaces than on overglazed and dual-ion-exchanged surfaces.

2. After immersion in saliva, natural-glazed and polished surfaces became rougher, hence resulting in a higher level of Candida adhesion on these surfaces.

3. Statistically similar results were obtained between the clinical strain and the GDH 2346 strain before and after immersion in artificial saliva.

\section{REFERENCES}

1) Fischer H, Marx R. Improvement of strength parameters of a leucite reinforced glass ceramic by dual ion-exchange. J Dent Res 2001; 80: 336-339.

2) Al-Wahadni A, Martin DM. Glazing and finishing dental porcelain: a literature review. J Can Dent Assoc 1998; 64: 580-583.

3) Fuzzi M, Zaccheroni Z, Vallania G. Scanning electron microscopy and profilometer evaluation of glazed and polished dental porcelain. Int J Prosthodont 1996; 9: 452458.

4) McLean JW. The science and art of dental ceramics. A collection of monographs. Louisiana State University School of Dentistry, Continuing Education Programme, 1974.

5) Ohi N, Ohno K, Kamohara H, inventors. G-C Dental Industrial Corp, assignee. Method for strengthening dental restorative material. US patent 4550030 (29 October 1985).

6) Giordano RA, Campbell S, Pober R. Flexural strength of feldspathic porcelain treated with ion exchange, overglaze, and polishing. J Prosthet Dent 1994; 71: 468-472.

7) Cook, PA., Griswold HW, Post AC. The effect of superficial colorant and glaze on the surface texture of vacuum-fired porcelain, fixed prosthodontics. Oper Dent 1984; 51: 476484.

8) Holloway JA, Denry IL, Rosenstiel SF. Surface layer characterization after dual ion exchange of a leucitereinforced dental porcelain. Int J Prosthodont 1997; 10: 136-141.

9) Scully C, Flint SR, Porter SR, Moos KF. Oral and maxillofacial diseases, $3^{\text {rd }}$ ed, Mosby Co., New York, 2004, pp. 114-115.

10) Odds FC. Candida and Candidosis, $2^{\text {nd }}$ ed, Bailliere Tindalll, London, 1988.

11) Calderone RA, Braun PC. Adherence and receptor relationships of Candida albicans. Microbiol Rev 1991; $55: 1-20$.

12) Roehm NW, Rodgers GH, Hatfield SM, Glasebrook AL. An improved colorimetric assay for cell proliferation and viability utilizing the tetrazolium salt XTT. J Immunol Methods 1991; 142: 257-265.

13) Wright PS, Young KA, Riggs PD, Parker S, Kalachandra S. Evaluating the effect of soft lining materials on the growth of yeast. J Prosthet Dent 1998; 79: 404-409.

14) Quirynen M, Marechal M, Busscher HJ, Weerkamp $\mathrm{AH}$, Darius PL, van Steenberghe D. The influence of surface free energy and surface roughness on early plaque formation. J Clin Periodontol 1990; 17: 138-144.

15) Radford DR, Challacombe SJ, Walter JD. Denture plaque and adherence of Candida albicans to denture-base materials in vivo and in vitro. Crit Rev Oral Biol Med 1999; 10: 99-116.

16) Wang YN, Wen GJ, Shi B, Pan XH. Adhesion of oral microorganisms on dental porcelain polished and glazed. Zhonghua Kou Qiang Yi Xue Za Zhi 2003; 38: 342-344.

17) Kokoti M, Sivropoulou A, Koidis P, Garefis P. Comparison of cell proliferation on modified dental ceramics. J Oral Rehab 2001; 28: 880-887.

18) Yıldırım MS. Hasanreisoglu U, Hasirci N, Sultan N. Adherence of Candida albicans to glow-discharge modified acrylic denture base polymers. J Oral Rehabil 2005; 32 : 518-525.

19) Paull KD, Shoemaker RH, Michael R. Boyd MR, Parsons JL, Risbood PA, Barbera WA, Sharma MN, Baker DC , Hand E, Scudiero DA, Monks A, Alley MC, Grote M. The synthesis of XTT: a new tetrazolium reagent that is bioreducible to a water-soluble formazol. J Heterocycl Chem 1988; 25: 911-914.

20) Sen BH, Chugal NM, Liu H, Fleischmann J. A new method 
for studying the adhesion of Candida albicans to dentin in the presence or absence of smear layer. Oral Surg Oral Med Oral Pathol Oral Radiol Endod 2003; 96: 201-206.

21) Hawser SP, Islam K. Binding of Candida albicans to immobilized amino acids and bovine serum albumin. Infect Immun 1998; 66: 140-144.

22) Chandra J, Mukherjee PK, Leidich SD, Faddoul FF, Hoyer LL, Douglas LJ, Ghannoum MA. Antifungal resistance of candidal biofilms formed on denture acrylic in vitro. J Dent
Res 2001; 80: 903-908.

23) Verran J, Maryan CJ. Retention of Candida albicans on acrlic resin and silicone of different surface topography. J Prosthet Dent 1997; 77: 535-539.

24) Ramage G, VandeWalle K, Wickes BL, Lopez JL. Characteristics of biofilm formation by Candida albicans. Rev Iberoam Micol 2001; 8: 163-170.

25) Leung VWH, Darvell BW. Artificial salivas for in vitro studies of dental materials. J Dent 1997; 25: 475-484. 